\title{
Enacting Maasai and Palaeoanthropological Versions of Drought in Oldupai Gorge, Tanzania
}

\author{
Patrick Lee \\ Department of Anthropology, University of Toronto, Canada/ patrickadam.lee@mail.utoronto.ca
}

\author{
Samson Koromo \\ Faculty of Arts and Social Sciences, University of Iringa, Tanzania
}

Julio Mercader

Department of Anthropology and Archaeology, University of Calgary, Canada

Charles Mather

Department of Anthropology and Archaeology, University of Calgary, Canada

\begin{abstract}
While palaeoanthropologists have travelled to Tanzania's renowned human origins site of Oldupai Gorge for over a century, lasting collaboration has not been established with the Maasai pastoralists who live there. This paper uses actor-network-theory and the concept of enactment to compare palaeoanthropological and Maasai livelihoods and to explore why collaboration has been infrequent. Here we show that scientists and locals navigated large political-economic contexts and expertly acquired resources in non-scientific and non-pastoral worlds. As part of these livelihoods, both Maasai peoples and researchers created and multiplied reality and ontologies by enacting composite - yet conflicting - versions of drought. Whereas Maasai peoples faced contemporary drought, palaeoanthropologists needed to focus on producing publishable data about ancient drought during short fieldwork seasons. Such livelihood exigencies have hindered meaningful collaboration between these groups who both dug in the Gorge to address drought. While the legitimisation of scientific ontologies is well-intentioned, Maasai drought unfortunately remains unaddressed.
\end{abstract}

Keywords: Oldupai, Olduvai, Maasai, palaeoanthropology, drought, ontology

\section{Introduction}

Northern Tanzania's Ngorongoro Conservation Area features abundant wild animals and spectacular landscapes that draw safari-bound tourists from around the planet, yet it also contains Oldu- pai Gorge, one of the world's most important sites for human origins research. As a result, other frequent guests to the region are palaeoanthropologists, who archaeologically excavate the fossils 
and stone tools associated with humanity's ancestors. Rarely noted in palaeoanthropological literature is that the lands surrounding Oldupai are home to a pastoralist Maasai society. Even though scientists have, for over a century, sought to illuminate the shared past of our species in what many regard to be a cradle of humankind (Clark, 2001; Leakey, 1978), there has seldom been meaningful collaboration between Maasai peoples and palaeoanthropologists. While a palaeoanthropological research partnership called Stone Tools, Diet, and Sociality is commencing a new chapter at Oldupai by collaborating with locals, many challenging issues remain.

We conducted fourteen weeks of ethnographic fieldwork in the region, during which we stayed at a paleoanthropological research camp located at the centre of Oldupai Gorge, participated in palaeoanthropological excavations, joined Maasai peoples in their pastoralist livelihood practices, and conducted interviews and focus groups with both communities. Throughout our research, we explored two primary research questions: how do Maasai and palaeoanthropological practices at Oldupai compare? Why have the groups rarely collaborated? This paper uses actor-networktheory to elucidate the practicalities behind the surprising lack of association between Maasai peoples and palaeoanthropologists. Members of each group engaged in practices that required navigating larger political-economic contexts, and both the Maasai and researchers tactfully obtained essential resources in non-pastoral and non-scientific worlds in order to support their valued pastoral and scientific livelihoods (Latour, 1987: 45-162). As part of these livelihoods, members of both groups shared in the practice of digging within the Gorge to address drought. While researchers possessed the financial and logistical means to conduct archeological excavations and thereby model an ancient drought and support their scientific livelihoods through writing publications, Maasai residents have been facing a multifaceted and livelihood-compromising drought that has gone unheeded, a drought that necessitates digging in the same Gorge for buried (and dirty) water. Each group created and proliferated reality and ontologies by enacting composite, yet conflicting, versions (Mol, 2002) of drought; one in the deep past and another in the present. These parallel enactments of drought demonstrate that palaeoanthropological and Maasai subsistence exigencies - respectively a publish-orperish academic climate and the necessity to find water - have been highly pressing matters during the relatively brief time in which palaeoanthropologists conduct fieldwork that have deferred and impeded collaboration in Oldupai Gorge.

\section{Background}

Maasai peoples practice, and are often associated with, pastoralism (Spear, 1993). This livestocktending livelihood prevails in locations where fickle rains make agriculture problematic. As pastoralists, the Maasai seasonally move livestock to dispersed water and forage, share resources and terrain with family and adjacent communities, and subsist on their animals' meat, milk, and blood (Fratkin, 2001: 3-4; Nelson, 2012: 4). During dry seasons, Maasai pastoralists who live within the Ngorongoro Conservation Area (NCA) often migrate livestock to resources located in highland areas, and when the rains arrive, they move back to lowlands. This transhumant livelihood promotes the regeneration of forage (Århem, 1985: 189-194; Galvin et al., 2008: 261-264). Rather than damaging ecosystems (Coughenour et al., 1985), pastoral practices have actually been a key factor in the genesis of contemporary savannah ecosystems that tourists flock to East Africa to experience. Within these landscapes, iconic safari wildlife, domesticated animals, and Maasai populations live in congruence. Pastoralists such as the Maasai protect and sustainably utilise areas where forage is available during dry periods, thereby sheltering wildlife whose migrations take them beyond the arbitrary borders of national parks (Nelson, 2012).

While Maasai peoples are often associated with pastoralism, Spear (1993) explores how Maasai livelihood practices have long been more fluid than such ascriptions suggest. Spear (1993) writes that it was sometime before 1000 AD that the contemporary Maasai's ancestors, who engaged in both agriculture and pastoralism, began moving southward from North Africa to what is now Tanzania and Kenya and began to 
more intensively practice pastoralism in the plains of the Great Rift Valley. They eventually became part of an emerging ethnic division of livelihood labour, forming around the eighteenth century, in which Maa-speaking people claimed the mantle of pastoralists while Okiek peoples and Bantu peoples respectively identified as huntergatherers and agriculturalists. However, Maasai pastoralists have long depended on exchanges of services, goods, and people with these agriculturalists and hunter-gatherers they defined themselves against, meaning that the 'pure' pastoralism that emerged was on the one hand a way to retain jurisdiction of pastoral resources yet on the other has been linked to modes of production outside the pastoral economy (Spear, 1993). Maasai peoples often espouse a 'pastoral ideal', that being a livelihood dedicated to tending livestock (Igoe, 2006), and Spear (1993) explains that they cemented and revitalised their pastoral ideal in the twentieth century when they forged alliances with colonists against other ethnic groups, and when colonists spatially divided pastoralists, hunter-gatherers, and agriculturalists in the Rift Valley.

The nation now known as Tanzania was colonised by Germany in 1885 and Britain in 1918 (Ngowi, 2009: 262), a period in which foreign actors took control of land, often by establishing farms or national parks (Bushozi, 2017: 8-9). The Tanzanian Maasai started to lose access to rangelands during this colonial era. The British administration instituted Serengeti National Park (SNP) in 1940, and upon the 1959 separation of a section of SNP that became the NCA, the British Government removed the Maasai from SNP. Unfortunately, SNP houses key Maasai water sources, and the Colonial Government did not bring many development projects to Maasai rangelands. While the 'Game Parks Laws Miscellaneous Amendments Act of $1975^{\prime}$ resulted in the creation of the Ngorongoro Conservation Area Authority; an organisation that actively nourishes Maasai, wildlife, and tourism interests in a region deemed a 'multiple land use area'; Maasai peoples have faced some challenges following Tanzania's 1961 independence. The World Bank and the International Monetary Fund endorsed neoliberal policies that ended up diminishing spending on education and health- care, policies that also saw the conversion of Maasai pastoral rangelands in ways that seemingly more productive and 'modern' economic industries could be implemented. Lowland wildebeest populations in the NCA have flourished due to conservation projects, yet these animals bring diseases to Maasai livestock. Since tourist infrastructure claims a lot of the water remaining within the NCA, the Maasai's highland resource caches are becoming congested, which exacerbates livestock disease conditions. Combined with increases in human populations, established forms of pastoralism in the region are no longer fully viable, and cultivation restrictions and limited access to participation in the tourism industry impede the Maasai's livelihood diversification options within the NCA (Galvin et al., 2008; Hodgson, 2011: 64-75).

Highlighting the fluidity of Maasai livelihoods and the espousal of the pastoral ideal, Maasai peoples have left for work outside the NCA as a means to support their pastoral lives within. Whereas the 1992 lifting of a cultivation ban in the NCA inspired most Maasai residents to start tending crops on a small scale, 2012 saw the reintroduction of the ban, and McCabe et al. (2014) write that their young Maasai interlocutors from the NCA have migrated to urban areas in search of employment as guards or in factories. These migrants often kept working until they were able to purchase livestock and thereafter return to their homes (McCabe et al., 2014), the NCA lands so popular with tourists.

Safari tourism in 2007 brought $\$ 1.6$ billion to Tanzania (Nelson, 2012), money that infrequently reaches Maasai communities. While the Maasai's pastoral livelihood contributes to the vitality of Tanzania's renowned ecosystems and thus its tourism industry, an entrenched yet misguided conviction that pastoralists overgraze pastures has guided evictions of the Maasai from rangelands (Nelson, 2012). Parties have sought to turn Maasai peoples away from pastoralism, which many have portrayed as obsolete. Concurrently, remunerative tourist mementos depict Maasai as archaic icons of primeval African landscapes (Hodgson, 2011: 64-70). Explaining that such representations embody and convey expectations that Maasai peoples cannot 'modernise' and that pastoralism 
harms environments, Galaty (2002) suggests that these ideas lead some decision makers to regulate the Maasai, which downplays actual Maasai interests and views.

Besides tourists, other visitors to the NCA are scientists. In 1911, a German butterfly aficionado named Wilhelm Kattwinkel came upon Oldupai's scientific resources (Leakey, 1978: 151). After Louis Leakey maintained that humanity's origins could be uncovered in East Africa, Mary Leakey excavated the legendary skull of Zinjanthropus boisei at the Gorge. This 1959 discovery catapulted Oldupai into public consciousness and cemented it as a prime location for palaeoanthropological research, especially since the Gorge's renowned stratigraphy provides an exemplary window into human origins (Clark, 2001). Through interdisciplinary means, palaeoanthropologists unearth and investigate the bones and stone tools associated with extinct hominins, the ancestors of contemporary humans. Palaeoanthropologists explore the life histories, diets, and sociality of hominins by reconstructing the climatic shifts and environmental contexts that impacted on our prehistoric ancestors (Keenleyside and Lazenby, 2011: 189-193).

All varieties of archaeologist - including palaeoanthropologists - engage in the practice of excavating, and in doing so, selectively remove and thereby produce specific kinds of evidence that they can use to reveal conceptions of the past. Thus, archaeology can make possible, stabilise, extend, and naturalise political discourse, interests, and truths (Abu El-Haj, 2001: 1-21). Despite representations of science as detached from society (Latour, 1987, 1993a) the field-based practice of archaeology overtly occurs in specific temporal and spatial landscapes. Archaeology can never be removed from the social, political, and institutional contexts in which it exists and reconstitutes, and other groups often make claims to the landscapes and traces that archaeologists seek (Abu El-Haj, 2001: 1-21).

A palaeoanthropological project that recognises such issues is Stone Tools, Diet, and Sociality (SDS), a palaeoanthropological partnership between environmental specialists, biologists, geologists, social scientists, and palaeoanthropologists from institutions located in numerous countries. SDS's interdisciplinary collaborations are producing myriad new insights that are vital for understanding humanity's emergence (Favreau 2019; Mercader et al., 2018a; Mercader et al., 2018b; Mercader et al., 2019; Soto et al., 2019; Soto et al., 2020a; Soto et al., 2020b; Tucker 2018; Tucker et al., 2020). Furthermore, SDS aspires to curb the history of neocolonial research at Oldupai by collaborating with the local Maasai, and Maasai peoples shared in such desires for collaboration.

We used actor-network-theory (ANT) to investigate and try to explain the various social groupings and associations at Oldupai. With ANT, an ethnographer documents social interactions, relationships, and various groups as temporary associative networks between 'actants' - diverse entities that include objects, facts, humans, nonhumans, ideas, and abilities. The ANT framework posits that groups form to accomplish specific objectives. This formation results from authoritative spokespeople establishing associations between actants, thereby creating some ensembles while also invalidating other ensembles. If one of these ensembles or actor-networks becomes 'potent', it may inspire action in others. When an association between actants withstands disassociation, it then becomes a discrete actant itself and is available to be brought into other associations (Finlay, 2014; Latour, 1993a: 158-236, 2005; Smart and Smart, 2017: 29-65).

Latour and Woolgar (1986: 105-179) demonstrate the above process by documenting how a group of scientific researchers agreed that a certain grouping of actants, including multiple scientific ideas, laboratory technologies, and experimental results, conclusively determined the chemical composition of Thyroptropin Releasing Factor. Even though Thyroptropin Releasing Factor might not consist of the particular variety of amino acids that scientists agreed upon, it became a new ontological entity that researchers across disciplines could use as a tool - another actant - in other associations. Latour (1987: 93-214) explains that while many feel that an understanding of an ever-present nature is why scientific debates resolve, ANT shows how settled debates actually produce nature. Moreover, with ANT, society is also a product of various associations; and the variety of connections between 
society, science, and technology illustrate that there are no absolute distinctions between social and scientific realms. For example, to support their laboratories and the science within them, scientists acquire resources/actants in the variegated social worlds beyond laboratory walls.

Thus, ANT sheds light on scientific understandings of nature, yet it can also be applied to myriad domains (Latour, 1993a: 158-236, 2005: 87-120). Ontology is the "branch of metaphysics that concerns itself with what exists" (Blackburn, 2008: 260), and ANT underscores how through practice, reality and ontologies can become multiple (Goldman et al., 2016: 28-32). In an ANT-aligned ethnographic study of disease, Mol (2002) introduces 'enactment': within two separate Dutch hospital departments, diverse practices enact multiple objects that share the same name, which subsequently proliferates reality and ontologies. In the outpatient clinic, doctors temporarily enact 'atherosclerosis' through diagnostic interviews and physical examinations with patients; while in the pathology ward, the same disease is 'done' through dissection and microscopy of tissue. Rather than being two subjective perspectives on the same objective disease within bodies, these exclusive practices give rise to different entities that are both called 'atherosclerosis'. Since there are many variations in the way this disease is enacted, even within outpatient clinics, there are nearly limitless multiplicities of reality (Mol, 2002: 1-51).

Mol (2002: 44-164) explains how various modes of coordination unite the multiple versions of enacted atherosclerosis. When diagnoses coincide, they can enact atherosclerosis in partnership, yet when techniques diverge in diagnoses, the single object can be maintained by finding faults in one of these methods. Moreover, rather than abandoning the incongruent results of diagnostic techniques, physicians can compile the different versions of atherosclerosis that emerge, producing a 'composite' disease. On the other hand, potentially conflicting enactments of atherosclerosis can simultaneously exist by remaining isolated within their respective sites of diagnosis. These 'distributions' of reality permit patientspecific treatments, and the word 'atherosclerosis' helps to coordinate communication between these place-specific enactments, preventing complete fragmentation. Entities (which in ANT terminology would be 'actants') such as knives, patient records, and corpses all play key roles in the myriad practical enactments of disease, ailments that then become new entities ('actants'). If others attribute facticity to the enacted disease, treatment follows. Assorted types of medical professionals then bring the enacted disease into new practical associations: treatments in surgery wards that 'counteract' the malady (Latour, 1987; Mol, 2002: 44-164).

In an application of Mol's (2002) enactment concept, Goldman et al. (2016) eschew the epistemological/perspective-based approach, which would begin with the assumption that there is a lone reality that members of different groups gaze upon and that scientists have unclouded and exclusive access to it (Goldman et al., 2016; Latour, 1993b: 96-112). Instead, Goldman et al. (2016) investigate how scientific and Maasai practices establish what a drought, ontologically speaking, is for members of each group. Both climate researchers and Maasai peoples astutely surveyed different arrays of culturally relevant actants, which resulted in discord between the groups regarding the year in which drought occurred. Unfortunately, Maasai peoples residing in areas not officially designated as zones needing relief can miss out on assistance. The authors accentuate how paying attention to ontology legitimises non-Western methods of knowing the world, an approach that flattens seemingly axiomatic ontological hierarchies that influence policy makers to only consider the supposed supremacy of scientific models when formulating decisions.

Goldman et al. (2016) demonstrate how Maasai pastoralists navigated political-economic forces, such as enduring colonial-era border impositions and the implications of top-down decisions. Rather than assuming the existence of stable and pre-ordained social contexts and forces, an ANT framework has the analyst instead regard 'society' and 'the social' as transient associations between exceedingly diverse types of actants (Latour, 2005) that may be mobilised on vast scales (Latour, 1993b: 96-124). In addition to the aforementioned political-economic forces that the Oldupai Maasai face - such as lucrative safari tourism that contrib- 
utes to eviction from lands, along with neoliberal reductions in social service expenditures - a potent force is the erroneous and influential view of Maasai pastoralists as archaic (Galaty, 2002; Galvin et al., 2008; Hodgson, 2011; Nelson, 2012). When promoters, writers, and artists depict Maasai peoples as timeless, Oldupai's locals appear premodern (Latour, 1993b).

Latour (1993b) writes that "We Have Never Been Modern": while members of so-called 'modern' societies visualise massive permanent shifts from archaisms, such as the seemingly anachronistic 'premodern' practice of making associations between 'nature' and 'society', all societies build 'hybrid' networks. Members of 'modern' cultures, especially scientists, strive to progressively sort out immutable nature from the polluting subjectivity of society. This practice fuels assumed breaks from the past and downplays the construction, within 'modern' societies, of hybrid networks that are comprised of myriad actants that 'moderns' may define as variably contemporary or primitive, natural or social. For Latour (1993b), 'symmetrical anthropology' entails investigating and comparing hybrid networks - which consist of ostensibly 'natural' and 'social' elements that are themselves both natural and social wherever they manifest. Latour (1993a: 230-236, 1993b: 13-112) declares that while many accord scientists sole authoritative access to 'nature', we must refrain from placing knowledge systems in hierarchies, as we all make knowledge by establishing sundry associations.

To debunk narratives that depict Maasai peoples as anachronistic, narratives that on many occasions work to inform policy decisions, Galaty (2002) advocates constructing normalising counter-narratives that acknowledge Maasai pastoralists as humans who have human yearnings and necessities, demonstrate that the Maasai practice their customs because they are proud of them, and recognise that the dynamic Maasai are denied access to the boons of 'modernity' that they often seek. We hope that our symmetrical approach (Latour, 1993b) throughout the following pages paints a humanising picture of life for Maasai peoples and for the researchers who make their living at Oldupai Gorge. While the Maasai participants in this study espoused great pride in their pastoral identity, they also drew on a long history of livelihood fluidity (Spear, 1993; McCabe et al., 2014) as they diversified their livelihoods and ventured into non-pastoral worlds. This paper will demonstrate that such ventures were aimed at supplementing and realising the Maasai 'pastoral ideal': a livelihood centered around livestock (Igoe, 2006).

\section{Methods}

Inspired by science and technology studies scholarship that highlights how practice creates reality for people (Goldman et al., 2016; Latour, 1987; Mol, 2002), our research at Oldupai was guided by two overarching research questions: how do the dayto-day practices of palaeoanthropologists and Maasai pastoralists, at a flagship scientific research locality, compare and contrast? Why have Maasai peoples and palaeoanthropologists, for over a century, rarely collaborated? Endorsed by the University of Calgary's Conjoint Faculties Research Ethics Board and aided by Mol's (1995) Maa language learning handbook, we secured Tanzanian permits and began exploring these questions by conducting ethnographic research amongst Oldupai Maasai communities. Samson Koromo - a Maasai scholar - assisted in translating the study's research protocol and interviews, and Samson Koromo and Patrick Lee regularly discussed how the project was and should be progressing. We collaborated with key informants whom we came to know during a 2015 pilot study, and we used snowball sampling to find others interested in contributing, meaning that the interests of community members directed the course of inquiry (Cohen, 1984: 223-225; Hammersley and Atkinson, 2007: 104-105).

Maasai homesteads consist of one or more family units (McCabe et al., 2010: 323-324) whose integration is a primary value and foundation for collective autonomy (Sharif and Bugo, 2015: 631-633). Thus, we employed focus groups (Buzinde et al., 2014: 26) at Maasai homesteads to explore how members of families view their lives at Oldupai. We engaged in 9 focus groups that featured females and males from all of the age-sets within which Maasai societies are organised (Spencer, 2003: 15-37). We also conducted 15 
semi-structured interviews with warriors, elders, youth, age-set leaders, women, mothers, and Maasai pastoralists employed by researchers. Maasai community members welcomed our participant observation in their villages, at community events, and as they practiced their pastoral livelihoods, which let us gain a contextual understanding of daily life (Camfield et al., 2009: 11). Interlocutors at Oldupai conveyed all of the direct quotes that are presented in this paper.

Ethnographic researchers can explore the standpoints of both non-scientists and scientists as a means to thoroughly comprehend the impacts that science makes on other groups (TallBear, 2013: 23-25). Thus, to holistically examine Oldupai and to understand how the discipline of palaeoanthropology affects the Gorge and the Maasai, we chose to 'study up' (Nader, 1969; TallBear, 2013: 17-18) and conduct ethnographic research amongst palaeoanthropologists. We used participant observation at palaeoanthropological dig sites and at scientific research camps. We spent our nights at these camps and had daily personal conversations and group discussions with researchers that were nearly identical in form to our interviews and focus groups amongst the Maasai.

Beyond anthropological symmetry, which entails examining all actor-networks equally (Latour, 1993b: 90-129), Callon (1984) calls for 'generalized symmetry': utilising a singular etic vocabulary to describe all entities. Thus, in the following text, we use the term 'actants' to refer to the myriad entities that were relevant to palaeoanthropological and to Maasai actor-networks. Nonetheless, rather than expunging insightful and distinctive cultural lexicons (Miettinen, 1999: 190-192), we strive to strike a balance between the emic and the etic by analysing the discussions in which our informants engaged and by making use of common ANT terminology. In this undertaking, our goal is to avoid contributing to any misguided and unjustified distinctions between scientists and locals (Latour, 1993b: 96-112).

\section{Results}

\section{Palaeoanthropological drought}

Palaeoanthropological fieldwork was typified by digging. Each sunrise, the SDS team climbed down Oldupai's steep walls in order to excavate at various sites that the team's prior surveys of the landscape, along with previously published research, had indicated would be bountiful in traces of the past. However, it was not only the highly tangible remnants of hominins - such as fossils and stone tools - that SDS excavated, as some team members dug into the stratigraphy that comprised the Gorge's walls. By digging at a series of vertical points and collecting samples of sediments that were progressively laid down through time over the past two million years (Mollel and Swisher, 2012), the researchers collected sediment samples that contained entities such as biomarkers and phytoliths (discussed below). SDS thus collected remnants of numerous ancient ecosystems and environments that hominins had lived in. Researchers immediately placed the sediment into sample bags to prevent the influx of other substances that may complicate analyses of the samples, and later transported the bags back to a contaminant-free clean laboratory in Canada where sought-after traces of the past, such as phytoliths, would be delicately extracted from the sampled sediment.

SDS researchers also constructed a mobile clean laboratory over their archaeological excavations while at Oldupai, a structure that prevented contemporary residues from contaminating the stone tools that the team unearthed from a large three metre by three metre excavation (see Lee et al., 2019). Confident that the residues adhering to lithics were ancient, SDS later analysed the stones at the clean laboratory in Canada as a means to understand how hominins used tools for processing food. However, this 'pure' science, which had a foundation of digging in numerous spots around Oldupai Gorge, also depended on the support of associations with countless types of extra-laboratory actants/resources.

Scientists must diplomatically acquire resources in the 'non-scientific' world beyond laboratory walls (Latour, 1987: 45-162), where they must also navigate cultural, economic, and 
political contexts that are themselves assemblages of actants (Latour, 2005). Surrounded by vast tracts of seasonally-desiccated backcountry, SDS needed to bring a wide variety of items with them in order to conduct the archaeological activities inside the mobile laboratory. Implements included trowels, screwdrivers, hammers, permanent markers, sieving screens, GPS devices, tape measures, a power generator, a HEPA air filter, air conditioners, starch-free clothing, nails, rope, pins, tape, thermometers, computers, cameras, notebooks, and sample bags. With no access to Wi-Fi nor to a library, palaeoanthropologists relied on previously-obtained excavation skills and theoretical knowledge. Researchers required assistance from an exceedingly wide variety of items and people, as archaeological assistants used generator-powered jackhammers, shovels, and wheelbarrows to remove large chunks of the ground. Once they had exposed sought-after layers, researchers could then begin to systematically search for bones and stone tools.

Archaeology is field-based; a science that always occurs in unique spatial and temporal contexts (Abu El-Haj, 2001: 20-21). To effectively respond to Oldupai's harsh landscape, palaeoanthropologists constructed a camp that featured tents, a communal meal pavilion, an outdoor cooking pit, latrines, and generator-induced electricity during select morning and dusk hours. The camp harboured bottles of water, food, plates and cutlery, and generator fuel. Prior to each evening meal, researchers, students, and assistants shared freshly-popped corn while attentively listening to a daily-rotating cast of lecturers deliver scholarly presentations with the assistance of a laptop and projector. The camp's hired attendants prepared meals while researchers and their assistants were away at excavation sites, swept the sand that the ever-present warm breeze constantly blew into the meal pavilion, and guarded the area from potential intruders. Nonhumans assisted in this latter task, as dogs protected the camp from hyenas and ostriches during the twilight hours, seemingly in exchange for table scraps.

We participated in a supply run to a settlement located 71 kilometres east of the camp. With a local driver, and assisted by research permits that allowed us to travel through the Ngorongoro gates, we traversed rutted dirt roads and arrived in Karatu. With a list of scientific and subsistence items in hand, we hopped between roadside kiosks, gas stations, a gated water outlet, and a central market. At this chaotic marketplace, we wandered through countless rows of kiosks, each featuring a vendor offering food items for which one had to negotiate a price. Not knowing how to do this, we fortunately found a friend of the camp's chef, who borrowed our shopping list and gathered each item on our behalf. Saving the team countless hours, her expertise was an irreplaceable asset to conducting research at Oldupai.

In an ANT framework (Callon, 1984; Latour, 1987, 1993a, 2005; Smart and Smart, 2017: 37), the distinguished leaders of palaeoanthropological teams coordinated networks of associations between multifarious actants, including humans, nonhumans, ideas, theories, objects, and abilities. Such networks were transient, as scientists conducted fieldwork during their institutions' summer months, a period that coincided with Tanzania's dry season. The associations facilitated specific action: enabling scientific work in a remote and grueling location. As the SDS project continues, its spokespeople will create stability by periodically re-coordinating these associations and assemblages of actants.

As a science that takes place in the field, archaeology occurs in - and reconstitutes - specific social and political contexts (Abu El-Haj, 2001: 20-21). Many of the actants that supported the 'pure' science within the Gorge were quite costly. In a world characterised by capitalism, neoliberalism, and reduced public expenditures on higher education (Blim, 2000: 27-31; Crewe and Axelby, 2013: 89-90, 159; Ylijoki, 2003: 307-310), palaeoanthropologists had to engage in a cycle common to academic disciplines (Finlay, 2014: 145-181; Latour and Woolgar, 1986: 187-230; Rabinow, 1996: 19-31): obtaining funding, conducting research, and producing credential-bestowing publications that secure continued funds. During the summer, researchers were able to escape the rigours of academic funding cycles that prevailed in their home institutions (Rabinow, 1996: 19-31) - along with the frustrations of top-down administrative decisions and policies - and used funding to acquire items such as research permits. These 
documents allowed palaeoanthropologists to conduct excavations at specified sites in the Gorge, which is located in the seemingly pristine NCA. Like its neighbouring national parks - which harbour important dry season water sources that Maasai peoples can no longer access - the NCA is not fully 'natural'. Rather, the NCA is a created piece of wilderness that attracts tourists and income in the same capitalistic world economy that researchers had to navigate. The NCA is a social-natural hybrid, and is the landscape that both palaeoanthropologists and Maasai peoples pursued their livelihoods in (Blim, 2000: 27-31; Crewe and Axelby, 2013: 89-90, 159; Cronon, 1995; Galvin et al., 2008; Hodgson, 2011: 64-75; Latour, 1993b; Nelson, 2012).

Researchers had a relatively short timeframe in which to conduct their livelihood-securing field research. Combined with the significant costs of archaeological supplies, camp items, research permits, and transportation across the planet; scientists focused on reconstructing the past as a means to publish academic publications, a key component of palaeoanthropological subsistence. On most teams, female and male researchers equally carried out excavations and wrote papers. One of SDS's mandates was to address a disproportionate quantity of African scholars excavating and publishing in the field of palaeoanthropology, a discipline largely controlled by outsiders to the continent (Shepherd, 2002: 205; Wadley, 2014: 209). Palaeoanthropologists listed as a co-author every researcher who had contributed to a project, and each contributor then shared in the all-important credentials that the act of publication conferred (Finlay, 2014: 145-181; Latour and Woolgar, 1986: 187-230). These papers also immortalised and extended some of the temporary associations - the associations between scientists in complementary fields, in particular - that the spokespeople of research groups forged while in Oldupai.

SDS researchers sought to illuminate the forces that drove humanity's emergence, and their baseline was modelling a period of fluctuating - and generally increasing - aridity that transpired in the Oldupai region 1.8 to 1.3 million years ago. Palaeoanthropologists were seeking to understand connections between this long-term drought and how ancient hominins began producing a variety of stone tools called the Acheulean, how hominins used such tools for processing food, and how carnivore-free patches of vegetation and water within a gradually opening and formerly forested landscape might have inspired new hominin social arrangements and behaviours. A researcher eloquently emphasised to us the centrality of this drought and the importance of not solely analysing fossils and stone tools: "It is not just archaeology that we are interested in, but the total environmental change".

Engaging in what palaeoanthropologists called a 'multi-proxy approach', researchers examined an amalgamation of various traces of past environments that they had excavated - such as biomarkers and phytoliths - in order to clarify the environmental conditions that may have influenced hominins to change their patterns of behaviour and to develop the Acheulean stone tool industry roughly a million and a half years ago. Lipid 'biomarkers', such as normal ( $n$-) alkanes, are chemically inert organic compounds that resist biodegradation throughout extremely large stretches of time, and analysing the isotopic values of biomarkers that are found in the sediments that surround buried stone tools can reveal changes in past plant composition and availability of water (Eglinton and Eglinton, 2008; Patalano, 2019). Biomarker research that SDS scientists conducted confirmed a drying and warming trend at an Oldupai Gorge site in the deep past, and demonstrated that the site was likely a riverine forest surrounded by a mosaic-like landscape that featured both heavily treed areas and more open environments (Patalano et al., 2017). Another trace of the past are 'phytoliths', which begin to form when live plants absorb silica and the silica subsequently fills cell spaces. While plants eventually die, these silica casts of plant cells can preserve for millennia, allowing researchers to compare the shape of such phytoliths to those from reference collections of contemporary vegetation in order to understand the types of plants and environments that existed in the past (Gallagher et al., 2015: 1-2; Itambu, 2020; Zhang et al., 2011). SDS researchers analysed phytoliths that they collected at three other Oldupai sites and revealed that they indicated a diverse, gradually opening, 
and progressively drying landscape (Itambu et al., 2017).

This long-term drought became the ancient environmental context in which SDS explored a variety of connections and associations between tool types, tool use, and hominin diet and social behaviours. Through various practices, SDS was enacting (Mol, 2002) a drought that occurred in the deep past. In an ANT framework, the researchers harnessing biomarkers and the scientists using phytoliths each made particular associations between heterogeneous actants - such as theories, methodologies, new data, laboratory techniques, and the countless supplies and relationships that made possible excavations at particular Oldupai Gorge sites - to enact this drought. Illustrating how actants need not be material, researchers established and corroborated the drought's existence and subsequently mobilised the idea of this ancient arid period into new associations. Such associations included those that allowed SDS to establish new scientific facts about prehistoric hominins through writing publications, publications that also support academic livelihoods (Finlay, 2014: 145-181; Latour, 1987, 1993a: 158-236, 2005; Latour and Woolgar, 1986: 187-230; Mol, 2002: 44-164; Mortensen, 2016: 61-62; Rabinow, 1996: 19-31; Smart and Smart, 2017: 37).

Thus, abiding by the 'multi-proxy' approach, researchers enacted (Mol, 2002: 1-51) drought by establishing different arrays of associations, such as those associated with either biomarkers or phytoliths. Rather than discovering a singular nature, researchers used these particular practices to enact two different versions of the same bygone drought, multiplying reality and ontologies. However, much like the composite disease diagnoses that Mol (2002: 53-117) outlines, SDS researchers could compile these site-specific practical enactments, thereby turning the composite drought into a foundation in which to explore other as-of-yet unclarified connections between stone tools, the landscape, and ancient diets. Researchers referred to this drying period as a singular event, preventing complete fragmentation (Mol, 2002: 108-117) of the enacted drought(s).
The drought had profound effects on humanity's shared past in Oldupai yet allowed contemporary scientists to continue making palaeoanthropological discoveries. Due to the relative brevity of field seasons, the costs of field research in a place distant from their homes, and the need to produce credibility-granting publications based on their research in a flagship research locality; palaeoanthropologists spent their energies exploring bygone times, such as the implications of the ancient drought. Navigating such exigencies, along with possessing the financial and logistical means to bring water to the research camp, meant that a contemporary drought - one affecting the Oldupai of today and the people who live there - usually remained peripheral to enacting the past.

\section{Maasai drought}

One afternoon, we were walking with some researchers and a Maasai warrior to a palaeoanthropological dig site. Our route through the sharp acacias took us down the Gorge's walls and through its dried-out basalt base. Upon reaching this parched bedrock, the warrior showed us a hole. A metre deep, two metres wide, and surrounded by a fence of barbed acacia tree branches that kept wild animals at bay, the hole harboured traces of water. A few days later, we were walking with a Maasai elder. We eventually found ourselves meandering through the bottom of the Gorge, and came across two Maasai girls who were crouched beside a hole in the ground. The girls had a donkey with them, along with two large containers. Further on, we passed a pool of water that was surfacing before our eyes. A girl emerged from the acacias and allowed her goats to drink from the pool. The elder explained that this saline water was not ideal for human consumption, yet using a shovel to dig a hole, he proclaimed that buried water was more drinkable. Thus, it was not only palaeoanthropologists whose livelihoods centred around digging in Oldupai Gorge. As the following pages will show, these digs were also a means to address desiccation, yet this reduction in water was much different from that being reconstructed by researchers.

The Maasai's established brand of pastoralism depends on unobstructed access to communal 
resources (Galvin et al., 2008: 274) and making associations with a wide variety of actants. We joined Maasai pastoralists as they left their villages in the morning and herded livestock to forage, and as they acquired water for their own consumption, for their livestock, and for medicinal soups. These soups contained numerous medically-active plants (Chapman et al., 1997), and interlocutors explained that their ethnomedical resources were absolutely vital since biomedical facilities were located nowhere near Oldupai. Maasai pastoralists placed the blood and meat of livestock into soups, and at other times drank their animals' milk.

To support their livelihoods in Oldupai and at home, palaeoanthropologists navigated large forces - such as the consequences of global capitalism and neoliberalism - and forged a wide variety of associations. Comparably, politicaleconomic forces that are also tied to the spread of capitalism and neoliberalism have carved out natural/social hybrid landscapes - lucrative and ostensibly 'natural' spaces such as Serengeti National Park that Maasai peoples have been evicted from - and have compromised the above brand of established pastoralism in the NCA by fragmenting rangelands and restricting the Maasai's access to dry season water sources (Blim, 2000: 27-31; Crewe and Axelby, 2013: 89-90, 159; Cronon, 1995; Galvin et al., 2008; Hodgson, 2011: 64-75; Latour, 1993b; Nelson, 2012).

While conceptions of 'nature' vary between knowledge systems (Satsuka, 2015: 6-7), a wide variety of analyses have explored the creation of protected 'natural' spaces across Africa, where the proliferation of such spaces has engendered countless disputes (Neumann, 1998). Conservation frameworks tend to envision separations between 'social' and 'natural' realms (Saj et al., 2006), and Brockington (2002) defines the widespread practice of evicting local people whose livelihoods depend on engaging with environments to be 'fortress conservation', which can be seen in various points in Tanzania's history. European imperialism and colonialism were accompanied by a mindset that rigidly separated human and natural/animal worlds, exemplified by the eviction of Maasai peoples from Serengeti National Park (McCabe et al., 1992; Walley, 2004: 170-174). Following the nation's 1961 inde- pendence, conservation projects have almost always omitted the knowledge of rural people while relying on that of 'experts' and scientists, even if those projects incorporate local populations (Walley, 2004). Conservation actors have been more recently focusing on the spaces surrounding Tanzanian parks that wildlife migrate into (Goldman, 2009: 342), and the expansion of neoliberal frameworks in Tanzania has seen the promotion of Wildlife Management Areas (WMAs), spaces beyond park boundaries where local communities are encouraged to forge partnerships with foreign investors to develop wildlife-based businesses (Igoe and Croucher, 2007). However, it would seem that fortress conservation (Brockington, 2002) lives on, as Igoe and Croucher's (2007) research revealed that countless members of local communities had not been informed of - nor consented to - WMAs being implemented and felt that WMAs precluded access to natural resources. Explaining that those communities who are adjacent to parks and who can partake in WMAs are usually conceptualised merely as tools for the agendas implemented by conservation agencies, Goldman (2003) suggests that two shifts in conservation frameworks must materialise in order for projects such as WMAs to be effective and to truly move on from fortressstyle exclusionary management. The first shift is now frequently realised and entails regarding local people as people who can be partnered with, yet the second and much more elusive shift is the act of legitimising - instead of excluding - the knowledge of local communities. As this paper will show, we join calls for comparable shifts (Ichumbaki et al., 2019) to begin characterising palaeoanthropological research within protected 'natural' spaces such as the NCA.

Another large and related force that Maasai peoples face is the lingering idea - despite evidence demonstrating how pastoralism is ecologically beneficial - that Maasai pastoral livelihoods are damaging to Tanzania's famed protected spaces that tourists come to see (Nelson, 2012). This notion that downplays Maasai perspectives and concerns (Galaty, 2002) is a powerful actant that Maasai peoples must navigate, and is made of other actants such as tourist memorabilia that paints the Maasai as 
archaic and timeless (Hodgson, 2011: 64-70). While modernity does not exist according to the qualifications established by 'modern' societies, in which humans completely separate 'natural' entities from the 'social' (Latour, 1993b: 67-90), the creation of 'natural' spaces and the eviction of 'premodern' people from them highlight that the idea of modernity remains a powerful and influential force.

These various top-down forces - assemblages of actants that are making established forms of pastoralism nonviable (Galvin et al. 2008) - have dissolved what were relatively stable (Smart and Smart, 2017: 54) Maasai actor-networks. For example, actants essential to pastoralism, such as crucial dry season water sources, lay in national parks that are next to the NCA and inaccessible to Maasai peoples. Comparable to scientists acquiring key resources in non-scientific or 'social' realms to support their scientific livelihoods and 'pure' science within laboratories (Latour, 1987: 45-162), Oldupai Maasai made ventures out into non-pastoral worlds, forging novel associations and obtaining heterogeneous resources/actants that could support 'pure' pastoralism. Social structures do not perpetually reappear generation after generation (Rosaldo, 1980: 1-28); Maasai peoples had to renegotiate the existence of their pastoral actor-network. They are not a 'timeless' society.

Maasai interlocutors often explained that they were staying in the challenging NCA region because it was their home, yet also because goats and sheep - unlike cattle - could thrive in extremely arid conditions: "we like it here because of the goodness of our pastoralism, especially for our goats and sheep. The plain is good for the sheep and goats". We learned that these small stock animals would die from diseases and frigid temperatures in highlands, yet also that since it was the ever-lengthening dry season, numerous warriors had left the permanent Oldupai villages to take cattle to mountainous regions. In one of many types of modifications to established forms of 'pure' pastoralism, Oldupai Maasai forged new associations and acquired key resources by making adjustments to prevailing gendered social roles (Wangui, 2008: 369-370): whenever there were no males around to herd remaining livestock to forage and water, women and girls stepped in to fill this role.

Like researchers, Maasai revealed frustrations over navigating top-down decisions and forces. They also emphasised that their isolated rural homeland was lacking social services such as water, hospitals, and schools. While the Maasai placed great value on ethnobotanical medicines, they also desired hospitals. If Maasai peoples needed hospital attention, they had to sell livestock to raise funds for a journey to medical facilities. The closest of such facilities were in Endulen, over 60 kilometres from Oldupai. Maasai residents repeatedly stated that various groups have promised services and infrastructure, yet have never delivered. Many Maasai also felt as though they were not permitted to have what Maasai peoples deemed 'modern' developments because tourists arrive in the region looking for wilderness. These travellers bring large quantities of capital into Tanzania's economy (Nelson, 2012), yet Maasai communities have largely been unable to access tourism revenue (Galvin et al., 2008: 260-261). Thus, Maasai were seeking to acquire resources - actants that were not components of established or 'pure' pastoral practices - to support their animal husbandry.

Oldupai Maasai used to acquire food by trading with agriculturalists in the NCA, but a cultivation ban within the Conservation Area has made it difficult for Maasai to access items such as maize. Pursuing elusive cash, Maasai have begun selling their cattle or have migrated to unfamiliar urban areas. In Zanzibar, we talked to Maasai warriors who had migrated there to sell beaded goods to tourists or to perform dances in luxury hotels, hoping to acquire money to re-purchase liquidated cattle stocks. These migrants were also likely capitalising on the widespread representation of Maasai peoples as timeless and exotic (Galaty, 2002; Hodgson, 2011: 66-68; May and Ikayo, 2007). In Dar es Salaam, we observed Maasai women vending beaded jewelry, along with warriors selling medicinal plants that had originated in rural areas. These Maasai were making new associations to continue their pastoral ways, yet males who had attended a certain coming-of-age ceremony were not to interact with those who had not. Demonstrating how all societies are dynamic 
and adjust to historical happenings (Rosaldo, 1980: 1-28), Oldupai Maasai have begun initiating youth at a younger age than in the past. As a result, when these youth temporarily migrated to cities, they were able to interact and share resources with older Maasai, which strengthened support networks while away from the NCA.

The top-down partitioning of formerly open landscapes and a lack of access to dry season water caches was just one facet of the increasingly desperate water situation for Oldupai Maasai peoples. Parallel to palaeoanthropologists, Maasai pastoralists were enacting (Mol, 2002) drought. Similar to how multi-faceted conditions of scarcity within their actor-networks in 2009 led the Maasai peoples whom Goldman et al. (2016) worked with to declare and enact drought and subsequently move to other regions, despite influential climate scientists using simplistic rainfall measurements to instead declare 2010 to be the more severe drought year, various different members of Oldupai Maasai communities gauged the conditions of multiple factors and actants in order to announce the arrival of what they frequently called drought.

A decrease in rainfall was part of the enactment in Oldupai. The Gorge is a river that flows with bountiful water during the rainy season, yet it unfortunately dries up completely as the arid season annually sets in. In recent years, the wet season has become significantly shorter. Many Maasai pastoralists attributed this seasonal metamorphosis to global climate change, which will continue making unpredictable impacts on East African ecosystems (Galvin et al., 2008: 273-274). However, this drought was more complex than just reduced rainfall.

Diminished water availability made negative impacts on Maasai nutrition and health: the diminution of forage that came with an extended dry season worked to emaciate and kill livestock, thereby diminishing the meat and milk available for human consumption. Relatedly, rangeland fragmentation - such as what happens when Maasai are denied access to places that contain vital water sources - can create congestion of livestock and a subsequent proliferation of cattle disease (Galvin et al., 2008), and because of a higher prevalence of livestock diseases, many Oldupai Maasai are now apprehensive of consuming their animals' milk and blood. We spoke to multiple interlocutors who had gone over two days without consuming food, and when we asked a focus group if Maasai peoples ever stray from their famed diet of milk, blood, and meat, a Maasai man stated that "yes... the only way to take care of our children. It has come the time with no milk and meat, we have to buy [agricultural foods] for children". Such products were produced outside of the Conservation Area and could be purchased in settlements that were distant to Oldupai. Transport to these places was exceedingly challenging, yet agricultural goods could also be acquired from temporary Maasai markets and small trading kiosks located throughout the NCA.

Preparing preventative and curative soups was becoming difficult. Maasai interlocutors said that they absolutely required water in order to transform medicinal plants, which they defined as vital in the rural Oldupai region, into effective treatments. One man scoffed and laughed when asked if he could use these ethnobotanical resources without water. Furthermore, along with forage, medicinal plants were also disappearing, and this botanical exodus was tied to drought.

Not unlike the palaeoanthropological 'multiproxy' approach to modelling an ancient drought, in which various researchers with unique specialisations combined their distinctive enactments, different members of Oldupai Maasai communities brought their own concept of drought into being by making associations between the conditions of multiple different actants throughout the region. To enact drought, Maasai peoples combined knowledge about pastoralism that elders had passed down, the inability to enter neighbouring national parks, a shorter wet season, climate change, livestock diseases, food shortages, and disappearing botanical resources. This drought was also a composite enactment (Mol, 2002: 53-117): the drought consisted of the various aforementioned indicators, each a distinct practical enactment of drought engendered by different members of the community, which created multiple versions. For example, some Maasai peoples enacted the specific version of drought that related to the disappearance of 
botanical resources by making astute associations between a wide variety of plant and tree actants and their own theoretical knowledge regarding such resources' conventional viability and availability. The Oldupai Maasai community coordinated and prevented the complete fragmentation of this composite drought, which like a diagnosed disease "appears to be more than one - without being fragmented into many" (Mol, 2002: 151), by collectively referring to it in English as 'drought' and in their native tongue of KiMaasai as alamei. This term also translated to 'dry season', an increasingly complex period of thirst that Maasai interlocutors explained had not only been more severe and lengthy than it had been in past years, but was also being exacerbated by being unable to access formerly accessible dry season resources located in Serengeti National Park, which neighbours the NCA. Once this temporally- and communityspecific drought was enacted, Maasai pastoralists mobilised the all-encompassing drought into novel associations with other actants, becoming a foundation for further action.

The most common response to this drought entailed unearthing the remnants of water that had previously flowed through the Gorge; a river during rainy months. Maasai men dug holes in Oldupai's base, exposing water that livestock could consume on the spot. Females scooped the water into plastic jugs, loaded these containers onto donkeys, and brought the water home. This water was oftentimes saline and potentially unsafe: livestock frequently walked through the water, and Maasai peoples discussed how the lack of medical facilities and transportation in the area meant that children who had to drink "dead water" were suffering from brucellosis and were unable to acquire treatment in distant hospitals. Furthermore, many Maasai infants were suffering from diarrhea, one of the leading causes of death for Tanzanian youth (Mohamed et al., 2016: 33). A local, reflecting on the salty and dirty water, lamented that "[there is] no way out, we have to drink it". Each excavation only remained viable for two or three days before it ran dry, and as the dry season progressed, this buried water completely disappeared.

Palaeoanthropological enactment of drought facilitated the productive subsistence of researchers. Prior to enacting drought, scientists dug in the Gorge for myriad traces of the past in order to assemble and corroborate the idea of an ancient period of desiccation. The scientists then turned the concept of the drought into a backdrop - a contemporary actant - in which to engage in the present-day practice of exploring emerging ideas about the past, which they later published. Conversely, once the Maasai enacted drought and corroborated its objective existence, they sought to counteract it, actions analogous to the numerous practices that Mol (2002: 87-117) describes in which various types of doctor intervene with and treat an enacted disease. The most common of the remedial practices, digging in Oldupai's basalt floor for traces of water that was abundant in the recent past, came after the enactment of the drought ravaging present-day Oldupai. Facing such pressing issues and troubles, palaeoanthropological information about the deep past was on many occasions irrelevant to Maasai peoples.

Various members of Maasai and palaeoanthropological communities each enacted multiple versions of drought, thereby multiplying reality and ontologies, yet these numerous enactments hung together in two composite forms of drought. Each group's composite (Mol, 2002) drought was quite different, however: scientists desired bygone drought that was crucial to their subsistence and livelihoods, as drought became a vital part of publications, while the Maasai detested contemporary drought that was compromising their subsistence and livelihoods. Ultimately, these conflicting enactments of drought were actants that coexisted side-by-side via spatial distributions of reality (Mol, 2002: 87-117). Palaeoanthropological practices, such as digging within various specific archaeological sites throughout the Gorge and conducting experiments and research within laboratory settings, gave rise to a composite drought. Concurrent Maasai practices in other spots around the Oldupai region, such as judging and evaluating rainfall patterns, livestock numbers and viability, food and water availability, the implications of borders around protected spaces that restrict access to water and forage, and the condition of medicinal plants, enacted numerous versions of drought that hung together 
in a composite form that diverged from that of researchers. A different site-specific practice, digging in the base of the Gorge, was geared towards ameliorating such thirst.

\section{Discussion}

Applying an ANT framework at Oldupai demonstrates that Maasai and palaeoanthropological subsistence strategies had to effectively navigate large social, political, and economic contexts that were themselves massive assemblages of actants (Latour, 1993b: 96-124, 2005: 1-93). Locals and researchers both expertly acquired and assembled countless varieties of actants in non-pastoral and non-scientific worlds to support their respective livelihoods (Latour, 1987: 45-162). As part of their subsistence, both Maasai peoples and palaeoanthropologists created and multiplied reality and ontologies by enacting their own composite and group-specific versions of drought that ultimately conflicted (Mol, 2002), as one drought was reviled for its ongoing devastation to contemporary Maasai pastoralism while the other existed millions of years ago and was much sought-after for its capacity to contribute to palaeoanthropological publication-based livelihoods. The exigencies associated with Maasai and palaeoanthropological subsistence have been hindering the emergence of a meaningful interface between the groups, despite the fact that members of both dug in the Gorge to address drought: Maasai peoples have been excavating buried water due to facing devastating long-term water security and water safety issues, issues which may make palaeoanthropological information about the lives of hominins in the deep past seem irrelevant, whereas researchers were excavating traces of an ancient drought to navigate a publish-or-perish academic climate while conducting relatively brief and expensive fieldwork excursions, a research context that could make community engagement seem extraneous.

By using a symmetrical approach (Latour, 1993b) to understand the multiple drought-based livelihood exigencies that have impeded collaboration between Maasai and palaeoanthropological communities at Oldupai, this paper also demonstrates that theories and frameworks associated with the field of science and technology studies (STS) can be fruitfully employed to understand the construction of knowledge and ontologies located outside of academy-based science. This assertion is much in line with Nader's (1996) contention that Indigenous knowledges are in fact a component of humanity's rational scientific knowledge, since they are most often based on reasoning and experience. Nader (1996) argues that there are forms of rationality that are not identical with Western rationality, and thus that the West is not the only place where'scientific' dispositions emerge.

While we take inspiration from Goldman et al. (2016) in striving to flatten knowledge hierarchies in which it is only Western scientific frameworks that guide policy, we are also inspired by Ferguson's (2011) espousal of a politics that strives to experiment and to exercise power provisionally instead of merely engaging in the easy practices of condemnation and critique. Ferguson's (2011) politics are based on Foucault's proclamation that the world could never be without power - which entails influencing others' behaviour - along with Foucault's questioning of how power should thus be enacted. Likewise, we recognise that we are academy-based scholars whose research carries with it a certain sway, a sense of authority, and a capacity to reach distant audiences (Bourdieu, 1975; Brown, 2009; Goldman et al., 2016; Latour, 1993a; Reay, 2007), and Maasai interlocutors explicitly requested that we make the issues they face known to wider audiences. We suggest that when in a position to conduct research amongst non-academic communities who desire for policy makers to understand and address their realities, STS scholars have a responsibility to write publications regarding the ontologies (and associated knowledge) of those communities who exist outside of academia, thereby working within extant power structures to widely disseminate realities that are usually fairly localised and unheeded.

Archaeological practice can reconstitute the social, political, and economic contexts in which it operates, especially by extending official discourse (Abu El-Haj, 2001: 1-21), a discourse which in the case of Oldupai has been wellintentioned yet may be effacing or hiding Maasai ontologies. By enacting an ancient drought 
and by excavating hominin bones and stone tools in order to understand the evolutionary emergence of humanity, palaeoanthropologists were retrieving evidence of a shared human past in the region. This common past is a message that many organisations have promoted to tourists, who make massive contributions to Tanzania's economy. Helping to establish the Gorge as a place to uncover scientifically and economically valuable discoveries - findings that illustrate the commonalities between all humans in an all-toodivisive world - may have inadvertently contributed to shrouding Maasai existence in the Oldupai region (Abu El-Haj, 2001: 1-21; Nelson, 2012; Staniforth, 2009: 167-169). If policy makers assume that scientists have a privileged perspectival access to a singular reality and provide legitimacy solely to scientific ontologies and entities by basing decisions only on scientific models, there can be profound consequences for underrepresented communities (Goldman et al., 2016; Latour, 1993a: 215-236, 1993b: 13-112). Numerous organisations -including academic publishing firms, funding agencies, and various governments and universities - legitimise the pursuit of palaeoanthropological drought. While this has been a scientifically significant and well-intentioned endeavour, two salient realities for Maasai peoples - drought and exclusion from palaeoanthropology - persist unrecognised (Galaty, 2002). Thus, not only have palaeoanthropological frameworks taken precedence over Maasai ontologies; palaeoanthropological fieldwork and research into a shared human past has also continued to exclude Maasai peoples within what is frequently described as a cradle of humanity.

Many members of Maasai communities sought to engage with palaeoanthropology as a means to initiate long-term careers in the discipline and to supplement their valued pastoral livelihoods that are being increasingly challenged within the NCA, a protected space where livelihood diversification options are limited (Galvin et al., 2008). Working with researchers is yet another example of Maasai peoples creatively acquiring resources in unfamiliar realms in order to continue practicing pastoralism (Latour, 1987: 145-162; McCabe et al., 2014). SDS has begun collaborations with Maasai pastoralists, who shatter common and unjust representations of Maasai communities as archaic peoples by possessing profoundly sophisticated knowledge that is equally logical to that of palaeoanthropologists (Lee et al., 2019), and these collaborations have not been extraneous. Rather, they have been mutually beneficial, as Maasai peoples are contributing their valuable knowledge to SDS research projects, SDS palaeoanthropologists and Maasai peoples are working together to co-produce new knowledge about the deep past, and Maasai interlocutors explained to us that the wages that they earned from working with SDS researchers allowed members of Maasai communities to supplement their pastoral practices by purchasing water and food from waystations located throughout the NCA during extremely scarce dry season periods. Palaeoanthropologists can thus help to legitimise and ameliorate Maasai concerns about drought and exclusion from research, yet much work remains, and we suggest two primary areas where such work should be concentrated.

\section{Two suggestions by way of conclusion}

One suggestion for future work is for STS scholars, as we propose research into the agency that people such as the Maasai practice when scientific research is carried out in their lands. For example, while African peoples have continually refused the top-down imperial and scientific practice of cartography, they have also contributed to mapmaking projects or appropriated cartographic frameworks to meet their own political goals (MacArthur, 2016). Relatedly, in an analysis geographically distant to this research but thematically affinitive, Mickel (2019) explores how local populations hired as labourers at nineteenth century archaeological excavations in the Middle East - workers who possessed valuable and indispensable skillsets and knowledge - had the agency to hinder or promote archaeological knowledge production. Some of these labourers resisted unfavourable working conditions and alienation, while others established their own expertise and indispensability to become trusted experts who oversaw excavations. We thus suggest further long-term ethnographic research amongst such 
researcher-local community collaborations at Oldupai or other human origins research sites (on the rare occasions they do arise) as a means to understand not only the reasons why researchers do or do not pursue collaborations, but also the agentive contributions provided by local populations to palaeoanthropology.

The second suggestion for future work is based on our ethnographic research but offered to other people who have vested interests in Oldupai Gorge, and this suggestion is inspired by Goldman's (2003) assertion that conservation projects can only be effective if they entail partnering with local people and legitimising their knowledge, along with the call by Ichumbaki et al. (2019) for human origins researchers in the NCA to not only hire Maasai peoples but to recognise their vast knowledge while co-producing knowledge with them. At Oldupai, it is still common for Maasai peoples to be excluded from research projects (Lee et al., 2019; Mehari and Ryano, 2016), meaning that our second suggestion is more fundamental than our first, and one that we hope this paper supports. As a normalising and humanising narrative of the Oldupai Maasai's exclusion (Galaty, 2002) from palaeoanthropology and the hardships they face, we hope that this paper can contribute - by becoming a potent actant in the forthcoming associations (Latour, 2005: 121-140) that both palaeoanthropologists and policy makers will forge - to a future in which the Maasai's devastating version(s) of drought becomes like that of palaeoanthropological researchers: firmly in the past.

\section{Acknowledgements}

This work was supported by the Canadian Social Sciences and Humanities Research Council under its Partnership Grant Program no. 895-2016-1017. We are also extremely grateful to the Social Sciences and Humanities Research Council's CGS Master's Program for the generous support furnished by the Joseph Armand Bombardier Canada Graduate Scholarship, award no. 766-2016-0787.

First, the authors acknowledge the essential contributions to the knowledge presented herein by the Indigenous communities, residents, and traditional owners of the land where we conduct research, the Maasai communities at Oldupai Gorge. We would also like to thank the University of Dar es Salaam, the University of Iringa, the Ngorongoro Conservation Area Authority, the Tanzania Commission for Science and Technology, the Department of Archaeology at the Max Planck Institute for the Science of Human History (MPI$\mathrm{SHH}$ ), the members of the SDS project, and all of the insightful and accommodating participants of this research. We also thank our reviewers for their helpful comments. Patrick Lee thanks Dr. Jamie Inwood for the endless insight and support.

This research was supported by the Social Sciences and Humanities Research Council of Canada. 


\section{References}

Abu El-Haj N (2001) Facts on the Ground: Archaeological Practice and Territorial Self-Fashioning in Israeli Society. Chicago: University of Chicago Press.

Århem K (1985) Two Sides of Development: Maasai Pastoralism and Wildlife Conservation in Ngorongoro, Tanzania. Ethnos 49(3-4): 186-210.

Blackburn S (2008) Dictionary of Philosophy. 2nd ed. Oxford: Oxford University Press.

Blim M (2000) Capitalisms in Late Modernity. Annual Review of Anthropology 29(1): 25-38.

Bourdieu P (1975) The Specificity of the Scientific Field and the Social Conditions of the Progress of Reason. Information (International Social Science Council) 14(6): 19-47.

Brockington D (2002) Fortress Conservation: The Preservation of the Mkomazi Game Reserve, Tanzania. Oxford: International African Institute in association with James Currey; Dar es Salaam: Mkuki Na Nyota; Bloomington: Indiana University Press.

Brown TL (2009) Imperfect Oracle: The Epistemic and Moral Authority of Science. University Park: Pennsylvania State University Press.

Bushozi PM (2017) Conservation and Sustainable Development of Palaeoanthropological Sites: A Case Study of Isimila in Iringa, Southern Tanzania. Proceedings of African Heritage and the Pillars of Sustainability Summer School: 1-20.

Buzinde CN, Kalavar JM and Melubo K (2014) Tourism and Community Well-Being: The Case of the Maasai in Tanzania. Annals of Tourism Research 44(1): 20-35.

Callon M (1984) Some Elements of a Sociology of Translation: Domestication of the Scallops and the Fishermen of St. Brieuc Bay. The Sociological Review 32(1): 196-233.

Camfield L, Crivello G and Woodhead M (2009) Wellbeing Research in Developing Countries: Reviewing the Role of Qualitative Methods. Social Indicators Research 90(1): 5-31.

Chapman L, Johns T and Mahunnah RLA (1997) Saponin-Like in Vitro Characteristics of Extracts from Selected Non-Nutrient Wild Plant Food Additives Used by Maasai in Meat and Milk Based Soups. Ecology of Food and Nutrition 36(1): 1-22.

Clark JD (2001) Mary Douglas Leakey 1913-1996. Proceedings of the British Academy 111: 595-614.

Cohen AP (1984) Informants. In: Ellen RF (ed) Ethnographic Research: A Guide to General Conduct, ASA Research Methods in Social Anthropology 1. London; San Diego: Academic Press, 223-229.

Coughenour MB, Ellis JE, Swift DM, et al. (1985) Energy Extraction and Use in a Nomadic Pastoral Ecosystem. Science 230(4726): 619-625.

Crewe E and Axelby R (2013) Anthropology and Development: Culture, Morality and Politics in a Globalised World. New York: Cambridge University Press.

Cronon W (1995) The Trouble with Wilderness; Or, Getting Back to the Wrong Nature. In: Cronon W (ed) Uncommon Ground: Rethinking the Human Place in Nature. New York: W.W. Norton \& Co, pp.69-90.

Eglinton TI and Eglinton G (2008) Molecular Proxies for Paleoclimatology. Earth and Planetary Science Letters 275(1-2): 1-16.

Favreau J (2019) Lithic Raw Material Characterisation at Olduvai Gorge, Tanzania. Master's Thesis, University of Calgary, Canada.

Ferguson J (2011) Toward a Left Art of Government: From 'Foucauldian Critique' to Foucauldian Politics. History of the Human Sciences 24(4): 61-68.

Finlay JL (2014) Elephants on a Flatbed Truck: Ethnography of an Integrated Applied Health Services Research Collaboration. PhD Thesis, University of Calgary, Canada. 
Fratkin E (2001) East African Pastoralism in Transition: Maasai, Boran, and Rendille Cases. African Studies Review 44(3): 1-25.

Galaty JG (2002) How Visual Figures Speak: Narrative Inventions of 'the Pastoralist' in East Africa. Visual Anthropology 15(3-4): 347-367.

Gallagher KL, Alfonso-Garcia A, Sanchez J, Potma EO and Santos GM (2015) Plant Growth Conditions Alter Phytolith Carbon. Frontiers in Plant Science 6(753): 1-9.

Galvin KA, Thornton PK, Boone RB and Knapp LM (2008) Ngorongoro Conservation Area, Tanzania: Fragmentation of a Unique Region of the Greater Serengeti Ecosystem. In: Galvin KA, Reid RS, Behnke RH Jr and Hobbs NT (eds) Fragmentation in Semi-Arid and Arid Landscapes: Consequences for Human and Natural Systems. Dordrecht: Springer, pp.255-279.

Goldman M (2003) Partitioned Nature, Privileged Knowledge: Community-Based Conservation in Tanzania. Development and Change 34(5): 833-862.

Goldman M (2009) Constructing Connectivity: Conservation Corridors and Conservation Politics in East African Rangelands. Annals of the Association of American Geographers 99(2): 335-359.

Goldman MJ, Daly M and Lovell EJ (2016) Exploring Multiple Ontologies of Drought in Agro-Pastoral Regions of Northern Tanzania: A Topological Approach. Area 48(1): 27-33.

Hammersley M and Atkinson P (2007) Ethnography: Principles in Practice. 3rd ed. London; New York: Routledge.

Hodgson DL (2011) Being Maasai, Becoming Indigenous: Postcolonial Politics in a Neoliberal World. Bloomington: Indiana University Press.

Ichumbaki EB, Cherin M, Masao FT and Moggi-Cecchi J (2019) Local People's Interpretations of the Hominin Footprints at Laetoli, Tanzania. Journal of Community Archaeology \& Heritage 6(2): 122-138.

Igoe J (2006) Becoming Indigenous Peoples: Difference, Inequality, and the Globalization of East African Identity Politics. African Affairs 105(420): 399-420.

Igoe J and Croucher B (2007) Conservation, Commerce, and Communities: The Story of Community-Based Wildlife Management Areas in Tanzania's Northern Tourist Circuit. Conservation and Society 5(4): 534-561.

Itambu MP (2020) Diversity of Plant Niches Available for Hominin Settlement During Upper Bed I- Lower Bed II: A Phytolith Perspective, Oldupai Gorge (Tanzania). PhD Thesis, University of Calgary, Canada.

Itambu M, Domiguez-Rodrigo M, Mabulla A, et al. (2017) Phytoliths Palaeolandscape During Bed II at Olduvai Gorge (Tanzania). Annual Meeting of the Paleoanthropology Society, Vancouver, Canada, 28-29 March 2017.

Keenleyside A and Lazenby R (2011) A Human Voyage: Exploring Biological Anthropology. Toronto: Nelson Education.

Latour B (1987) Science in Action: How to Follow Scientists and Engineers Through Society. Cambridge: Harvard University Press.

Latour B (1993a) The Pasteurization of France. Cambridge: Harvard University Press.

Latour B (1993b) We Have Never Been Modern. Cambridge: Harvard University Press.

Latour B (2005) Reassembling the Social: An Introduction to Actor-Network-Theory. Oxford: Oxford University Press.

Latour B and Woolgar S (1986) Laboratory Life: The Construction of Scientific Facts. 2nd ed. Princeton: Princeton University Press.

Leakey MD (1978) Olduvai Gorge 1911-75: A History of the Investigations. In: Bishop WW (ed) Geological Background to Fossil Man: Recent Research in the Gregory Rift Valley, East Africa. Edinburgh: Scottish Academic Press, pp.151-155. 
Lee P, Koromo S, Mercader J and Mather C (2019) Scientific Facts and Oral Traditions in Oldupai Gorge, Tanzania: Symmetrically Analysing Palaeoanthropological and Maasai Black Boxes. Social Science Information 58(1): 57-83.

MacArthur J (2016) Cartography and the Political Imagination: Mapping Community in Colonial Kenya. Athens: Ohio University Press.

McCabe JT, Leslie PW and DeLuca L (2010) Adopting Cultivation to Remain Pastoralists: The Diversification of Maasai Livelihoods in Northern Tanzania. Human Ecology 38(3): 321-334.

McCabe JT, Perkin S and Schofield C (1992) Can Conservation and Development be Coupled among Pastoral People? An Examination of the Maasai of the Ngorongoro Conservation Area, Tanzania. Human Organization 51(4): 353-366.

McCabe JT, Smith NM, Leslie PW and Telligman AL (2014) Livelihood Diversification through Migration among a Pastoral People: Contrasting Case Studies of Maasai in Northern Tanzania. Human Organization 73(4): 389-400.

May A and Ikayo FNO (2007) Wearing Illkarash: Narratives of Image, Identity and Change Among Maasai Labour Migrants in Tanzania. Development and Change 38(2): 275-298.

Mehari AG and Ryano KP (2016) Maasai People and Oldupai (Olduvai) Gorge: Looking for Sustainable People-Centered Approaches and Practices. In: Schmidt PR and Pikirayi I (eds) Community Archaeology and Heritage in Africa. Abingdon; New York: Routledge, pp.35-59.

Mercader J, Abtosway M, Bird R, et al. (2018a) Morphometrics of Starch Granules from Sub-Saharan Plants and the Taxonomic Identification of Ancient Starch. Frontiers in Earth Science 6: 1-34.

Mercader J, Akeju T, Brown M, et al. (2018b) Exaggerated Expectations in Ancient Starch Research and the Need for New Taphonomic and Authenticity Criteria. Facets 3(1): 777-798.

Mercader J, Clarke S, Bundala M, et al. (2019) Soil and Plant Phytoliths from the Acacia-Commiphora Mosaics at Oldupai Gorge (Tanzania). PeerJ 7: e8211.

Mickel A (2019) Essential Excavation Experts: Alienation and Agency in the History of Archaeological Labor. Archaeologies 15(2): 181-205.

Miettinen R (1999) The Riddle of Things: Activity Theory and Actor-Network Theory as Approaches to Studying Innovations. Mind, Culture, and Activity 6(3): 170-195.

Mohamed H, Clasen T, Njee RM, Malebo HM, Mbuligwe S and Brown J (2016) Microbiological Effectiveness of Household Water Treatment Technologies under Field Use Conditions in Rural Tanzania. Tropical Medicine and International Health 21(1): 33-40.

Mol A (2002) The Body Multiple: Ontology in Medical Practice. Durham: Duke University Press.

Mol F (1995) Lessons in Maa: A Grammar of Maasai Language. Lemek: Maasai Centre Lemek.

Mollel GF and Swisher CC III (2012) The Ngorongoro Volcanic Highland and its Relationships to Volcanic Deposits at Olduvai Gorge and East African Rift Volcanism. Journal of Human Evolution 63(2): 274-283.

Mortensen L (2016) Artifacts and Others in Honduras. In: Field L, Gnecco C and Watkins J (eds) Challenging the Dichotomy: The Licit and the Illicit in Archaeological and Heritage Discourses. Tucson: The University of Arizona Press, pp.56-74.

Nader L (1969) Up the Anthropologist: Perspectives Gained from Studying Up. In: Hymes D (ed) Reinventing Anthropology. New York: Pantheon Books, pp.284-311.

Nader L (1996) Anthropological Inquiry into Boundaries, Power, and Knowledge. In: Nader L (ed) Naked Science. Londres: Routledge, pp.1-25.

Nelson F (2012) Natural Conservationists? Evaluating the Impact of Pastoralist Land Use Practices on Tanzania's Wildlife Economy. Pastoralism: Research, Policy and Practice 2(1): 1-19. 
Neumann RP (1998) Imposing Wilderness: Struggles Over Livelihood and Nature Preservation in Africa. Berkeley: University of California Press.

Ngowi HP (2009) Economic Development and Change in Tanzania Since Independence: The Political Leadership Factor. African Journal of Political Science and International Relations 3(4): 259-267.

Patalano RV (2019) The Environmental Context of the Earliest Acheulean at Olduvai Gorge, Tanzania. PhD Thesis, University of Calgary, Canada.

Patalano R, Diez-Martín F, Domínguez-Rodrigo M et al. (2017) Molecular Isotopic Analysis Reveals Details on the Environmental Context of the Earliest Acheulean at Olduvai Gorge. Annual Meeting of the Paleoanthropology Society, Vancouver, Canada, 28-29 March 2017.

Rabinow P (1996) Making PCR: A Story of Biotechnology. Chicago; London: University of Chicago Press.

Reay M (2007) Academic Knowledge and Expert Authority in American Economics. Sociological Perspectives 50(1): 101-129.

Rosaldo R (1980) Ilongot Headhunting, 1883-1974: A Study in Society and History. Stanford: Stanford University Press.

Saj TL, Mather C and Sicotte P (2006) Traditional Taboos in Biological Conservation: The Case of Colobus Vellerosus at the Boabeng-Fiema Monkey Sanctuary, Central Ghana. Social Science Information 45(2): 285-310.

Satsuka S (2015) Nature in Translation: Japanese Tourism Encounters the Canadian Rockies. Durham: Duke University Press.

Sharif T and Bugo J (2015) The Anthropological Approach Challenges the Conventional Approach to Bioethical Dilemmas: A Kenyan Maasai Perspective. African Health Sciences 15(2): 628-633.

Shepherd N (2002) The Politics of Archaeology in Africa. Annual Review of Anthropology 31(1): 189-209.

Smart A and Smart J (2017) Posthumanism: Anthropological insights. Toronto: University of Toronto Press.

Soto M, Inwood J, Clarke S, et al. (2019) Structural Characterization and Decontamination of Dental Calculus for Ancient Starch Research. Archaeological and Anthropological Sciences 11(9): 4847-4872.

Soto M, Favreau J, Campeau K, et al. (2020a) Fingerprinting of Quartzitic Outcrops at Oldupai Gorge, Tanzania. Journal of Archaeological Science: Reports 29: 102010.

Soto M, Favreau J, Campeau K, et al. (2020b) Systematic Sampling of Quartzites in Sourcing Analysis: IntraOutcrop Variability at Naibor Soit, Tanzania (Part I). Archaeological and Anthropological Sciences 12: 1-14.

Spear T (1993) Introduction. In: Spear T and Waller R (eds) Being Maasai: Ethnicity and Identity in East Africa. London: J. Currey, pp.1-18.

Spencer P (2003) Time, Space, and the Unknown: Maasai Configurations of Power and Providence. London; New York: Routledge.

Staniforth A (2009) Returning Zinj: Curating Human Origins in Twentieth-Century Tanzania. Journal of Eastern African Studies 3(1): 153-73.

TallBear K (2013) Native American DNA: Tribal Belonging and the False Promise of Genetic Science. Minneapolis; London: University of Minnesota Press.

Tucker LL (2018) Bioavailable Strontium from Plants and Diagenesis of Dental Tissues at Olduvai Gorge, Tanzania. Master's Thesis, University of Calgary, Canada.

Tucker L, Favreau J, Itambu M, et al. (2020) Initial Assessment of Bioavailable Strontium at Oldupai Gorge, Tanzania: Potential for Early Mobility Studies. Journal of Archaeological Science 114: 105066.

Wadley L (2014) South African Middle and Later Stone Age research: A Retrospective. The South African Archaeological Bulletin 69(200): 208-212. 
Walley CJ (2004) Rough Waters: Nature and Development in an East African Marine Park. Princeton: Princeton University Press.

Wangui EE (2008) Development Interventions, Changing Livelihoods, and the Making of Female Pastoralists. Agriculture and Human Values 25(3): 365-78.

Ylijoki OH (2003) Entangled in Academic Capitalism? A Case-Study on Changing Ideals and Practices of University Research. Higher Education 45(3): 307-35.

Zhang J, Lu H, Wu N, Yang X and Diao X (2011) Phytolith Analysis for Differentiating Between Foxtail Millet (Setaria italica) and Green Foxtail (Setaria viridis). PLOS ONE 6(5):e19726. 